\title{
Studi Analisa Pasang Surut, Distribusi Air Tanah Payau dan Sedimen Serta Pengaruhnya Terhadap Pola Sebaran Mangrove di Kepulauan Karimunjawa
}

\author{
Fajar Hudoyo $^{1 *}$, Sugeng Widada ${ }^{1}$, Lilik Maslukah ${ }^{1}$, Baskoro Rochaddi ${ }^{1}$, Anindya Wirasatriya ${ }^{1}$ \\ dan Novi Susetyo Adi $^{2}$ \\ ${ }^{1}$ Departemen Oseanografi, Jurusan Ilmu Kelautan Fakultas Perikanan dan Ilmu Kelautan \\ Jl. Prof. H. Sudarto, SH Tembalang, Telp/fax (024) 7474698 Semarang 50275 \\ ${ }^{2}$ Pusat Riset Kelautan, Kementrian Kelautan dan Perikanan Republik Indonesia \\ Jl. Pasir Putih II No.636-694, RW.10, Ancol, Kec. Pademangan, Kota Jkt Utara, Daerah Khusus \\ Ibukota Jakarta 14430 \\ Email : *fajarhudoyo@students.undip.ac.id
}

\begin{abstract}
Abstrak
Karimunjawa merupakan salah satu pulau yang berada di sebelah utara Kota Jepara. Keberadaan mangrove di daerah ini menjadi daya tarik tersendiri dan dijadikan distinasi wisata berupa tracking mangrove di area Taman Nasional Karimunjawa. Sebagian mangrove di area ini memiliki keunikan yaitu bentuknya yang kerdil dibandingkan dengan mangrove di daerah lainnya yang diduga terkait dengan kondisi sedimen dan air tanahnya. Penelitian ini bertujuan untuk mengetahui pengaruh pasang surut, distribusi air tanah payau, dan sedimen dasar terhadap pola sebaran mangrove. Data yang diambil adalah sampel sedimen untuk mengetahui jenis sedimen dan kandungan $\mathrm{C}$ organik, salinitas, dan pasang surut. Sedangkan untuk mengetahui kondisi lapisan sedimennya digunakan metode geolitrik resistivity. Tipe pasang surut Karimunjawa yaitu campuran condong harian tunggal, distibusi air tanahnya berasal dari resapan air hujan dan daratan yang lebih tinggi yang mengalir pada sedimen dengan ketebalan sampai 9 meter dari permukaan tanah. Kandungan C organik pada tracking mangrove bervariasi antara $4-39 \%$. Hasil analisis menunjukkan bahwa sebaran mangrove yang jauh dari laut memiliki diameter yang lebih kecil antara $4-6 \mathrm{~cm}$ dan tinggi batang yang lebih tinggi antara $4-6 \mathrm{~m}$. Hal ini dikarenakan pengaruh pasang surut, distribusi air tanah, dan lapisan sedimen dibawahnya. Jenis mangrove ke arah daratan memiliki kerapatan dan tutupan kanopi yang lebih tinggi daripada jenis mangrove yang dekat dengan laut, sehingga mempengaruhi perbedaan nilai $\mathrm{C}$ organik dimana pada daerah dekat laut nilainya lebih kecil antara 4-9\% dan di dekat daratan lebih besar antara $10-39 \%$.
\end{abstract}

Kata kunci : Pasang Surut, Mangrove, Geolistrik, Sedimen, C Organik, Taman Nasional Karimunjawa

\begin{abstract}
Karimunjawa Island is located in the north of Jepara City. The existence of mangroves in this area becomes a tourist destination by forming tracking mangroves in the area of Karimunjawa National Park. Some mangroves in this area are unique since they are more dwarf than mangroves in other areas. This may be related to the condition of the sediment and groundwater. This study aims to determine the effect of tides, brackish groundwater distribution, and bottom sediments on the distribution pattern of mangroves. We collected sediment samples to determine the type of sediment and organic C content, salinity, and tides. Furthermore, to determine the condition of the sediment layer, the resistivity geoelectricity method is used. The tidal type in Karimunjawa is a mixed prevailing diurnal. The distribution of groundwater comes from the absorption of rainwater and surface runoff from higher land that flows on sediments with a thickness of up to 9 meters from the ground surface. Organic C content in mangrove tracking varies between 4 - 39\%. The analysis shows that the distribution of mangroves far from the sea has a smaller diameter between $4-6 \mathrm{~cm}$ and a higher stem height between $4-6 \mathrm{~m}$ which is related to the tides, distribution of groundwater, and sediment layers below. Mangroves toward the mainland have a higher density and canopy cover than mangroves close to the sea. This distribution affects the difference in organic C content where in the area near the sea the organic C content is low i.e., between 4-9\%, and near the mainland is high i.e., between $10-39 \%$.
\end{abstract}

Keyword : Tides, Mangrove, Geoelectric, Sedimen, Organic C, Karimunjawa National Park

\section{PENDAHULUAN}

Kawasan Taman Nasional Karimunjawa merupakan gugusan kepulauan yang berjumlah 27 pulau, terletak di Laut Jawa, dan termasuk di wilayah Kabupaten Jepara, Provinsi Jawa Tengah. Taman nasional Karimunjawa berjarak 45 mil laut dari ibu kota Kabupaten Jepara dan mempunyai luas 7.120 Ha. Beberapa pulau nya adalah Pulau Karimunjawa, Pulau Kemojan, Pulau Parang, Pulau Nyamuk dan Pulau Genting (BPS Kabupaten Jepara, Kecamatan Karimun dalam Angka, 2013). 
Karimunjawa memiliki kekayaan ekosistem pesisir dan laut meliputi mangrove, padang lamun, terumbu karang, ekosistem pantai dan pulau-pulau kecil. Dengan keanekaragaman dan kekayaan ekosistemnya, perairan Karimunjawa memiliki beberapa keunikan di banding kawasan perairan laut di lokasi lain, khususnya di perairan laut Pantai Utara Jawa (Kusnadi \& Fauziah, 2010).

Secara umum kondisi habitat mangrove di Indonesia dengan tipe komunitas jenis pohon dominan memiliki perbedaan jenis mangrove dari satu tempat dengan tempat lainnya. Faktor utama yang menyebabkan adanya zonasi pertumbuhan mangrove adalah jenis substrat dan kandungan bahan organik sedimen pada jenis mangrove. Peranan bahan organik dalam ekologi laut adalah sebagai sumber energi bagi tumbuhan maupun hewan dan sebagai zat yang dapat mempercepat dan memperlambat pertumbuhan sehingga memiliki peranan penting dalam mengatur kehidupan. Bahan organik dalam sedimen juga merupakan sumber kesuburan bagi pertumbuhan mangrove (Lestaru et al., 2018).

Menurut Perry dan Berkeley (2009), faktor lingkungan yang dapat menjadi habitat mangrove adalah kawasan yang memiliki suplai air payau yang cukup, substrat sedimen yang tebal, dan daerah tersebut masih mendapat pengaruh pasang surut atau daerah intertidal.

Kondisi mangrove di kepulauan Karimunjawa memiliki keunikan yaitu tumbuhan mangrove cenderung kerdil dan tumbuh dengan struktur tubuh yang kecil. Hal ini tentunya dipengaruhi oleh komponen lingkungan seperti kelimpahan unsur organik $(C, N$, dan $P)$ dan dasar perairan yang tersusun dari karang yang menyebabkan sedimen dasar memiliki ketebalan yang tipis. Selain itu, faktor oseanografi seperti pasang surut, salinitas, DO, sedimen dasar, dan suplai air tawar juga berpengaruh terhadap distribusi dan kondisi mangrove di Taman Nasional Karimunjawa.

Pasang surut dapat menyebabkan perpindahan dan pergerakan sedimen dasar sehingga mempengaruhi ketebalan sedimen yang menjadi habitat tumbuhnya mangrove. Pasang surut juga memiliki pengaruh terhadap dinamika air tanah yang diduga mempengaruhi distribusi air tawar dari dalam tanah. Oleh karena itu, urgensi penelitian ini dilakukan untuk mengetahui lebih lanjut hubungan faktor oseanografi yang saling berkaitan yaitu pasang surut, sedimen dasar dan distribusi air tanah payau, terhadap pola sebaran mangrove dan pertumbuhan mangrove yang cenderung kerdil di kepulauan Karimunjawa.

\section{MATERI DAN METODE}

Materi yang digunakan pada penelitian ini adalah data aliran air tanah yang diambil dari survey geolistrik, data sedimen dan data salinitas yang diperoleh dari survey lapangan, data sebaran mangrove yang diperoleh dari pengamatan dapangan dan data BTNKJ, serta data pasang surut yang diperoleh dari Badan Informasi Geospasial. Titik lokasi penelitian terdiri atas 8 stasiun sedimen, 15 Stasiun Geolistrik, dan 7 Stasiun salinitas dari sumur buatan.

\section{Pengambilan Data Geolistrik}

Pengambilan data geolistrik dengan metode Vertical Electrical Sounding (VES) menggunakan konfigurasi Schlumberger. Metode ini digunakan untuk menentukan nilai perubahan tahanan jenis untuk tiap-tiap lapisan pada suatu titik pengukuran (Febriana et al., 2017).

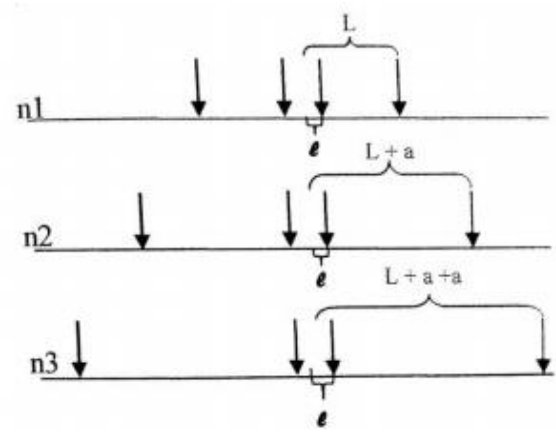

Gambar 1. Metode Pengambilan Data Geolistrik (Febriana et al., 2017) 
Akuisisi data geolistrik ini dilakukan dengan menginjeksikan arus listrik ke dalam bawah permukaan untuk mendapatkan respon dari bawah permukaan berupa tegangan listrik. Panjang lintasan setiap titik pengukuran antara 200 meter hingga 300 meter dengan menggunakan spasi arus AB/2 minimal 1 meter hingga maksimal 150 meter.

\section{Pengambilan Data Pasang Surut}

Data pasang surut diperoleh melalui permohonan data kepada Badan Informasi Geospasial (BIG) Bogor pada bulan September 2019 pada lokasi Taman Nasional Karimunjawa. Pengambilan periode data pasang surut mewakili musim peralihan II.

\section{Pengambilan Data Sedimen}

Pengambilan sampel sedimen dilakukan di 8 titik yang mewakili jenis mangrove yang ada di kawasan Taman Nasional Karimunjawa. Penentuan stasiun berdasarkan pengambilan data geolistrik dan keberadaan jenis mangrove dominan yang ada dilokasi. Sampel diambil dengan sedimen sekop sampai kedalaman 10$20 \mathrm{~cm}$, selanjutnya dimasukkan ke dalam kantong sampel dan disimpan dalam cool box yang berisi es batu untuk di analisis di laboratorium. Pengambilan sampel sedimen digunakan untuk mengetahui kandungan bahan organik dan jenis sedimen pada kawasan mangrove.

\section{Pengambilan Data Salinitas}

Data salinitas diambil menggunakan refraktometer pada 7 titik sumur buatan untuk mengetahui kadar garam air sampel. Data salinitas digunakan untuk mengetahui sebaran air tawar dan air asin pada kawasan tracking mangrove Taman Nasional Karimunjawa

\section{Analisis Data}

\section{Pasang Surut}

Data dari hasil pengamatan di lapangan kemudian dihitung dan dianalisa dengan metode harmonik yaitu metode Admiralty. Analisa harmonik metode Admiralty adalah analisa pasang surut yang digunakan untuk menghitung dua konstanta harmonik yaitu amplitudo dan keterlambatan fase. Djaja dalam Ongkosongo dan Suyarso (1989) mengemukakan metode Admiralty dimana permukaan air laut rata-rata diperoleh dengan menghitung konstanta-konstanta pasut.

\section{Distribusi Air Tanah}

Data yang diperoleh dari pengukuran dilakukan pengolahan 1D dengan menggunakan software Ipi2win. Pada dasarnya prinsip yang digunakan adalah pencocokan kurva, dimana perubahan kemiringan kurva merupakan indikasi perubahan nilai tahanan jenis dan posisi perubahan kemiringan kurva adalah indikasi perubahan kedalaman. Namun hasil dari pengolahan data ini adalah nilai tahanan jenis dan kedalaman minimum untuk masing-masing sounding. Interpretasi jenis litologi dan kandungan air tanahnya dilakukan dengan memperhatikan nilai resistivitas tiap lapisan dengan mempertimbangkan kond isi geologi setempat yang diperoleh dari pengamatan lapangan dan pengukuran salinitas air tanah dari sumur pantau yang dibuat.

\section{Jenis Sedimen dan Kandungan C Organik}

Metode yang digunakan untuk analisis ukuran butir sedimen merujuk pada McIntyre dan Holme (1984). Sampel sedimen dikeringkan dalam oven dengan temperature 1000C, kemudian diayak menggunakan sieve shaker dengan saringan berukuran $2 \mathrm{~mm} ; 0,5 \mathrm{~mm} ; 0,312 \mathrm{~mm} ; 0,125 \mathrm{~mm}$ dan $63 \mu \mathrm{m}$, lalu ditimbang berat masing-masing ukuran. Sampel sedimen yang lolos saringan berukuran $63 \mu \mathrm{m}$ digabungkan dengan sampel berukuran $0,125 \mathrm{~mm}$. Selanjutnya untuk mengetahui ukuran butir yang lebih kecil dilakukan pemipetan dicampur dengan sampel sedimen yang mengendap dalam aquades lalu dilakukan pemipetan. 
Tabel 1. Jarak dan Waktu Pemipetan

\begin{tabular}{|c|c|c|c|c|}
\hline $\begin{array}{c}\text { Diameter } \\
(\mathbf{m m})\end{array}$ & $\begin{array}{c}\text { Jarak Tenggelam } \\
(\mathrm{cm})\end{array}$ & Jam & $\begin{array}{l}\text { Waktu } \\
\text { Menit }\end{array}$ & Detik \\
\hline 0,0625 & 20 & & & 58 \\
\hline 0,0312 & 10 & & 1 & 56 \\
\hline 0,0156 & 10 & & 7 & 44 \\
\hline 0,0078 & 10 & & 31 & 0 \\
\hline 0,0039 & 10 & 2 & 30 & 0 \\
\hline
\end{tabular}

Kandungan karbon pada sedimen di uji menggunakan metode pengabuan, proses pengabuan menurut Mahasani et al., (2016) dan Fitriyah et al., (2016) adalah sebagai berikut :

1. Sampel sedimen diambil sebanyak 10 gr, direndam dengan $\mathrm{HCl} 6 \mathrm{M}$ kemudian bilas dengan aquades.

2. Sampel sedimen ditempatkan dalam cawan alumunium, kemudian dimasukan kedalam oven yang sudah diatur suhu $\left(60^{\circ} \mathrm{C}\right)$ dan waktunya $(48$ jam).

3. Setelah kering, sampel kemudian digerus atau dihaluskan dengan menggunakan mortar. Setiap subsampel yang telah dihaluskan tersebut ditempatkan kedalam kantong plastik.

4. Sampel yang sudah dihaluskan ditimbang sebanyak \pm 2 gram, kemudian ditempatkan pada crucible porcelain. Sampel tersebut dimasukan kedalam muffle furnace atau tanur dan dibakar dengan suhu $450^{\circ} \mathrm{C}$ selama 4 jam, kemudian ditimbang kembali.

\section{Salinitas}

Data salinitas diolah menjadi peta kontur sebaran salinitas menggunakan arcgis untuk mengetahui peta persebaran air tawar dan air asin. Selanjutnya di overlay dengan data lapisan tanah yang diolah dengan Ipi2win dan digunakan untuk interpretasi distribusi aliran air tanah.

\section{HASIL DAN PEMBAHASAN}

\section{Jenis Pasang Surut}

Dari perhitungan analisa harmonik menggunakan metode Admiralty diperoleh nilai amplitudo (A) dan kelambatan fase ( $\mathrm{g}^{*}$ ) yang dapat dilihat pada Tabel 2 . Berdasarkan Tabel 1, tipe pasang surut suatu perairan dapat ditentukan oleh perbandingan antara konstanta pasut harian utama (K1 dan O1) dengan konstanta pasut ganda utama (M2 dan S2). Dari hasil perhitungan, nilai Formzahl (F) yang didapatkan sebesar 1,577. Sehingga jenis pasang surut di pulau Karimunjawa memiliki tipe campuran condong ke harian tunggal, karena memiliki nilai Formzahl dengan kisaran antara 1,5 $<\mathrm{F} \leq 3$. Artinya, dalam satu hari terjadi satu kali air pasang dan air surut, tetapi terkadang terjadi dua kali pasang dan dua kali surut dengan tinggi dan periode yang sangat berbeda. Gambar 2.

Tabel 2. Komponen Pasang Surut Pulau Karimunjawa

\begin{tabular}{ccccccccccc}
\hline & $\mathrm{S}_{0}$ & $\mathrm{M}_{2}$ & $\mathrm{~S}_{2}$ & $\mathrm{~N}_{2}$ & $\mathrm{~K}_{1}$ & $\mathrm{O}_{1}$ & $\mathrm{M}_{4}$ & $\mathrm{MS}_{4}$ & $\mathrm{~K}_{2}$ & $\mathrm{P}_{1}$ \\
\hline $\begin{array}{c}\mathrm{A} \\
(\mathrm{cm})\end{array}$ & 69 & 2,9 & 15.5 & 4,7 & 18,8 & 10,1 & 0,6 & 1,1 & 4.2 & 6,2 \\
$\mathrm{~g}^{*}$ & 180.0 & 91,8 & 249,2 & 176,3 & 455,8 & 327,1 & 109,3 & 251,8 & 249,2 & 455,8 \\
\hline
\end{tabular}

$$
\mathrm{F}=\frac{A(K 1)+A(O 1)}{A(M 2)+A(S 2)}=\frac{18,8+10,1}{2,9+15,5}=1,577
$$




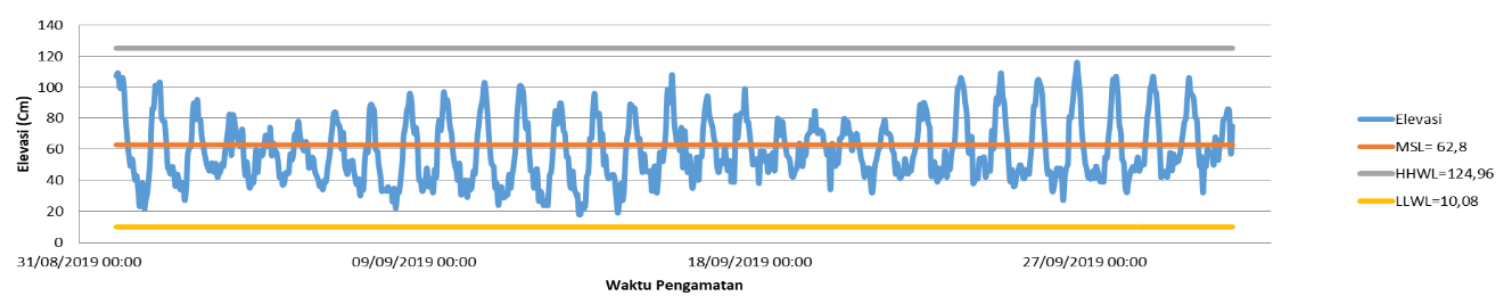

Gambar 2. Grafik Pasang Surut Karimunjawa

Demikian, dengan pola pasang surut tersebut dapat ditentukan range durasi waktu spring tide (pasang purnama) dan neap tide (pasang perbani). Elevasi MSL sebesar 0,628 m, HHWL sebesar $1,2496 \mathrm{~m}$ dan LLWL sebesar $0,1008 \mathrm{~m}$.

\section{Geolistrik}

Penentuan interpretasi jenis litologi tanah ini mengacu pada hasil log bor yang didapatkan saat membuat sumur pengamatan pengukuran air tanah yang berjumlah 7 titik. Saat pengeboran ditemukan beberapa jenis lapisan tanah diantaranya lanau dengan air asin, lanau pasiran dengan air asin, pasir dengan air asin, batu pasir, dan juga batu gamping. Berikut adalah nilai logbor yang digunakan dalam penentuan interpretasi jenis litologi tanah.

Tabel 3. Log Bor Penentuan Interpretasi Lapisan Litologi

\begin{tabular}{ccc}
\hline No. & $\begin{array}{c}\text { Nilai Resistivitas } \\
(\mathbf{O h m})\end{array}$ & Jenis Tanah \\
\hline 1 & $0-3$ & Lanau dengan air asin \\
2 & $3-10$ & Lanau pasiran dengan air asin \\
3 & $10-20$ & Pasir dengan air asin \\
4 & $20-100$ & Batu pasir dengan air asin \\
5 & $>100$ & Batu gamping dengan air asin \\
\hline
\end{tabular}

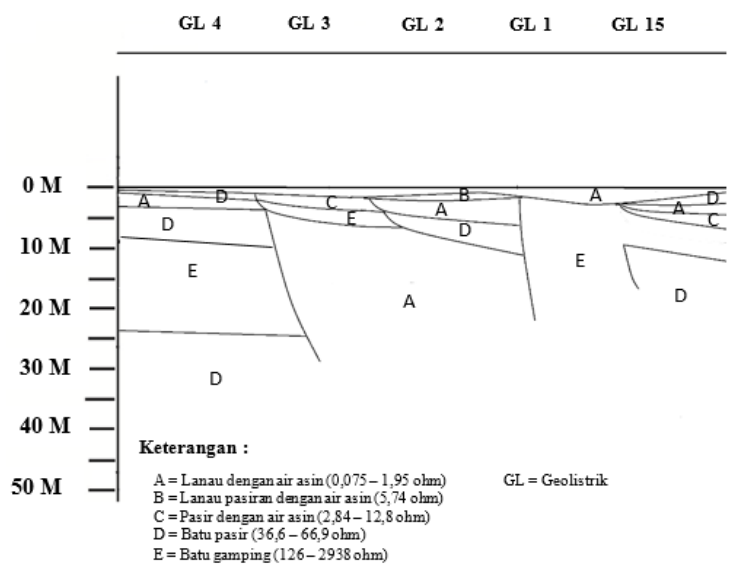

Gambar 3. Penampang Resistivitas Geolistrik Titik 4, 3, 2, 1 dan 15 


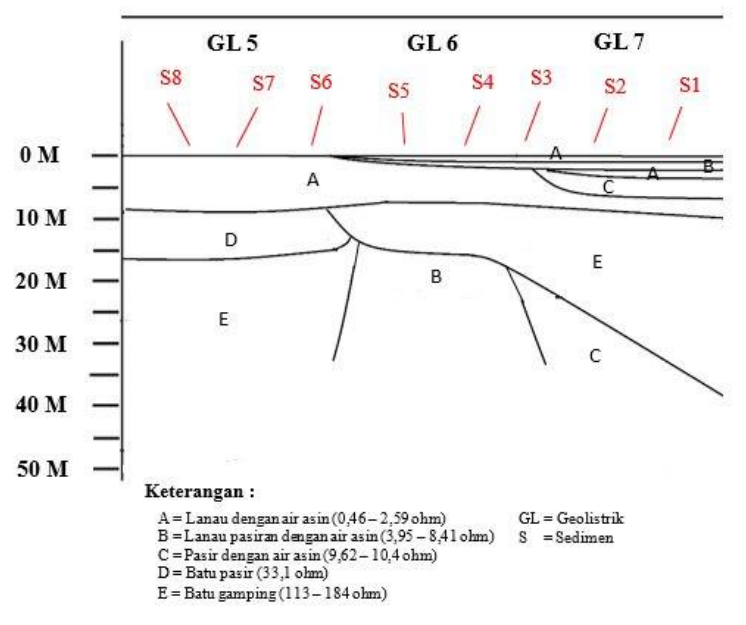

Gambar 4. Penampang Resistivitas Geolistrik Titik 5, 6 dan 7

\section{Salinitas}

Salinitas di area treking mangrove memiliki nilai $43-51$ ppt. Pengukuran salinitas dilakukan di sumur buatan yang memiliki kedalaman $30-86 \mathrm{~cm}$ dari permukaan tanah. Artinya, pada daerah treking mangrove ditemukan air asin karena nilainya diatas $30 \mathrm{ppm}$. Hal ini menjadi fenomena unik yang perlu dilakukan penelitian lebih lanjut untuk mengetahui penyebab tingginya salinitas di area treking mangrove.

Ketersediaan air tawar dan konsentrasi kadar garam sangat mempengaruhi keberlangsungan ekosistem dan sebaran jenis mangrove.

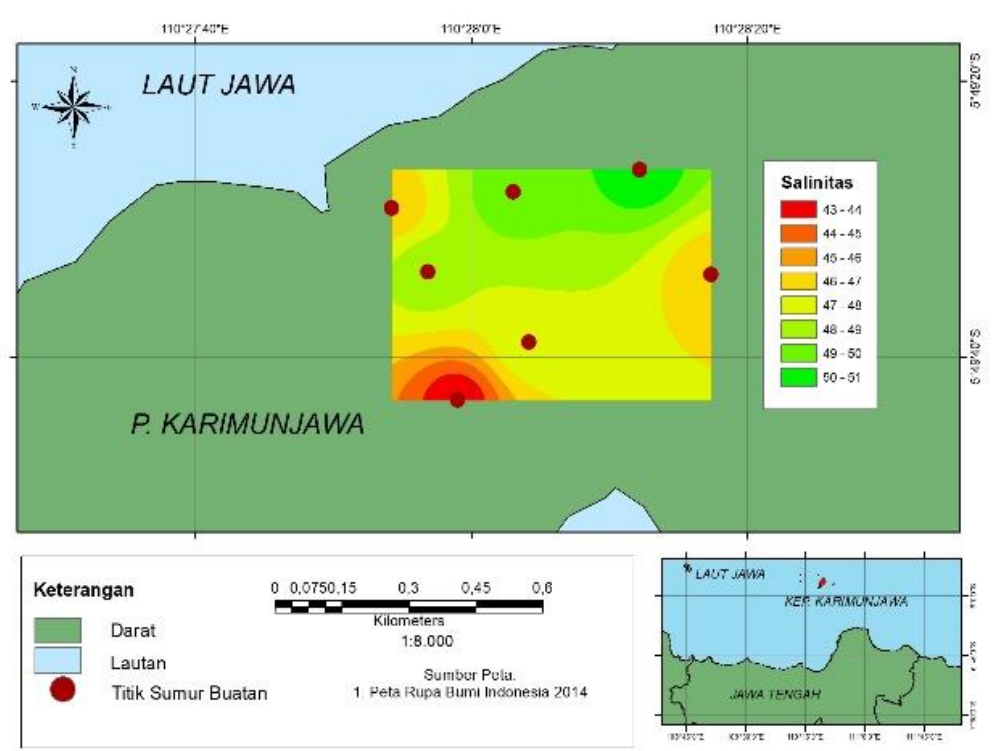

Gambar 5. Peta Kontur Salinitas

Ketersediaan air tawar tergantung dari frekuensi dan volume air dari sistem sungai, resapan air hujan, dan irigasi dari darat, frekuensi dan volume air pertukaran pasang surut, dan tingkat evaporasi ke atmosfir. Walaupun ekosistem mangrove memiliki mekanisme adaptasi terhadap salinitas yang tinggi, namun tidak adanya suplai air tawar yang mengatur kadar garam dan isi air tergantung dari tipe tanah dan sistem pembuatan irigasi (Nursal et al., 2005). 
Tabel 4. Data Salinitas Tracking Mangrove

\begin{tabular}{ccc}
\hline Nama & $\begin{array}{c}\text { Kedalaman } \\
(\mathrm{cm})\end{array}$ & $\begin{array}{c}\text { Salinitas } \\
(\mathrm{ppt})\end{array}$ \\
\hline Sumur 1 & 60 & 48 \\
Sumur 2 & 86 & 49 \\
Sumur 3 & 74 & 46 \\
Sumur 4 & 85.5 & 50 \\
Sumur 5 & 30 & 51 \\
Sumur 6 & 47 & 46 \\
Sumur 7 & 48.5 & 43 \\
\hline
\end{tabular}

\section{Sedimen}

Dari 8 titik pengambilan sampel, setelah dilakukan analisis granulometri, didapatkan hasil bahwa sedimen permukaan yang berada di kawasan tracking mangrove didominasi oleh pasir. Hal ini juga di dukung oleh data interpretasi geolistrik disekitar lokasi pengambilan sampel sedimen. Dari data geolistrik juga ditemukan bahwa di daerah tracking mangrove di dominasi oleh daerah akuifer sehingga memungkinkan lapisan dalam tanah dapat menyimpan air resapan yang berasalah dari air hujan maupun air yang mengalir dari daerah yang lebih tinggi.

Tabel 5. Jenis Sedimen Tracking Mangrove

\begin{tabular}{ccccc}
\hline \multirow{2}{*}{ Stasiun } & \multicolumn{3}{c}{ Fraksi Sedimen } & \multirow{2}{*}{ Jenis Sedimen } \\
\cline { 2 - 4 } & Sand (\%) & Silt (\%) & Clay (\%) & \\
\hline 1 & 99.260 & 0.600 & 0.125 & Pasir \\
2 & 99.180 & 0.700 & 0.100 & Pasir \\
3 & 99.100 & 0.710 & 0.100 & Pasir \\
4 & 99.200 & 0.600 & 0.090 & Pasir \\
5 & 99.100 & 0.780 & 0.110 & Pasir \\
6 & 99.100 & 0.770 & 0.110 & Pasir \\
7 & 98.900 & 0.850 & 0.190 & Pasir \\
8 & 98.900 & 0.900 & 0.120 & Pasir \\
\hline
\end{tabular}

Pada Tabel 6 dapat dilihat nilai d50 pada sedimen di 8 titik pengambilan sampel berkisar antara 0,35 sampai 1,2. Hal ini menunjukkan bahwa sebaran sedimen di 8 titik sampling di dalam tracking mangrove terdiri dari sedimen dengan butiran pasir halus, pasir sedang, dan pasir kasar. Pada daerah tracking mangrove ditemukan beberapa batu karang yang menunjukkan bahwa daratan tracking mangrove dulunya adalah daerah lautan atau yang tergenang dengan air laut. Batuan karang yang mengalami pelapukan di daerah tracking mangrove juga mempengaruhi jenis sedimen permukaan. Persebaran jenis sedimen pada daerah tracking mangrove dapat dipengaruhi oleh pasang surut dan juga posisi jarak dengan lautan ketika daerah tersebut masih tergenang oleh air laut.

Dari Tabel 7, dapat dilihat terdapat perbedaan nilai karbon organik pada 8 titik pengambilan sampel sedimen yang mewakili jenis mangrove di dalam tracking mangrove. Kandungan karbon organik tertinggi ada di titik 4 dengan $39.060 \%$, selanjutnya ada di titik 1,2, dan 5 dengan range 35,1 - 35,9\%. Kandungan karbon di 4 titik $(1,2,4$, dan 5) yang terletak di daratan memiliki nilai yang lebih tinggi dibandingkan nilai karbon di 2 titik ( 7 dan 8) yang berada di dekat laut. Hal ini disebabkan oleh banyaknya sesasah daun dan batang mangrove yang gugur di daerah daratan yang menutupi lapisan permukaan tanah. Dalam penelitiannya, dijelaskan bahwa daun mangrove yang jatuh ke sedimen menjadi sumber bahan organik, dan selanjutnya terdekomposisi menjadi unsur hara (Aini et al., 2016). 
Tabel 6. Nilai D50 Sedimen

\begin{tabular}{ccc}
\hline No & Stasiun & d50 (mm) \\
\hline 1 & 1 & 1,1 \\
2 & 2 & 1,2 \\
3 & 3 & 0,4 \\
4 & 4 & 1,1 \\
5 & 5 & 0,8 \\
6 & 6 & 0,7 \\
7 & 7 & 0,5 \\
8 & 8 & 0,35 \\
\hline
\end{tabular}

Tabel 7. Nilai C Organik Sedimen

\begin{tabular}{ccccc}
\hline No & Stasiun & Abu (\%) & BO $(\boldsymbol{\%})$ & C organik $(\boldsymbol{\%})$ \\
\hline 1 & 1 & 39.420 & 60.580 & 35.137 \\
2 & 2 & 39.360 & 60.640 & 35.171 \\
3 & 3 & 82.470 & 17.530 & 10.168 \\
4 & 4 & 32.655 & 67.345 & 39.060 \\
5 & 5 & 38.095 & 61.905 & 35.905 \\
6 & 6 & 57.807 & 42.193 & 24.472 \\
7 & 7 & 84.138 & 15.862 & 9.200 \\
8 & 8 & 92.505 & 7.495 & 4.347 \\
\hline
\end{tabular}
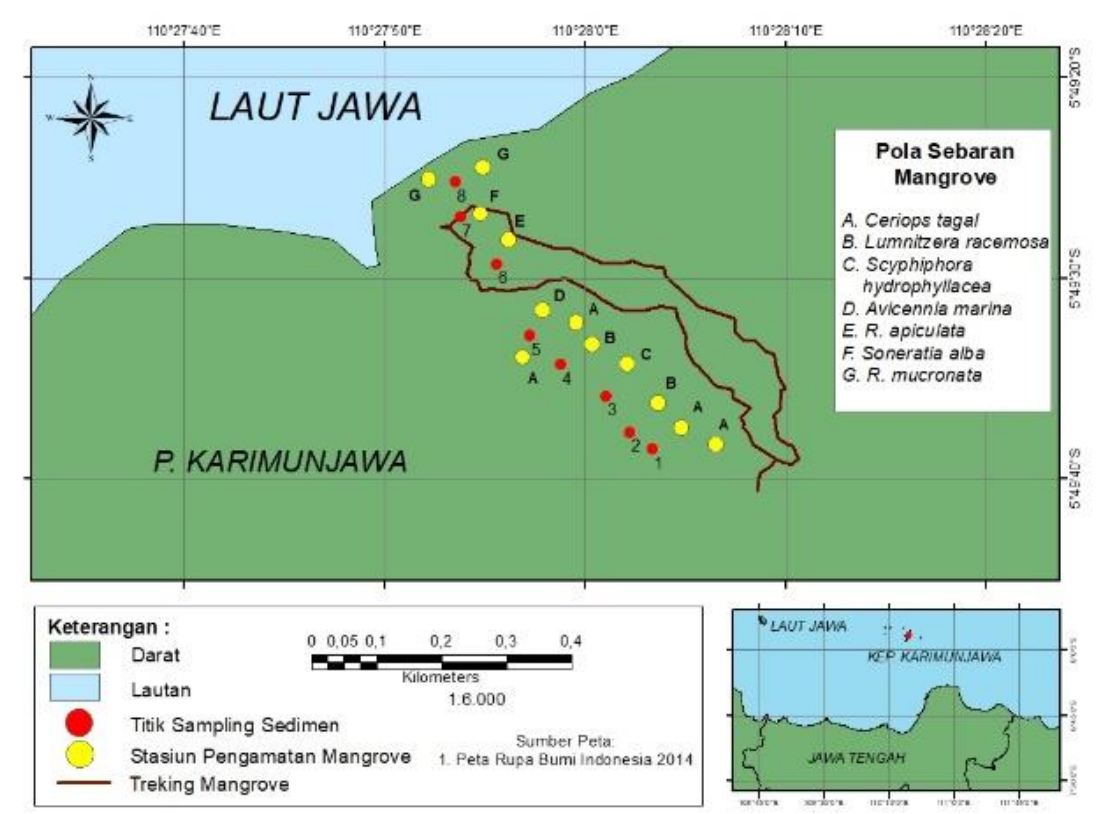

Gambar 11. Peta Sebaran Mangrove 
Distribusi air tanah pada Kawasan Taman Nasional Karimunjawa ditemukan pada kedalaman 0,4 9,5 yang terdiri dari formasi lapisan lanau dengan air asin, lanau pasiran dengan air asin, dan pasir dengan air asin yang merupakan lapisan akuifer pengikat air dan dapat mengalirkan air. Sedimen permukaan tracking mangrove didominasi oleh pasir serta guguran serasah daun dan batang mangrove sehingga memiliki kandungan C Organik yang berbeda. Pada kawasan dengan kerapatan dan tutupan kanopi yang tinggi yaitu berkisar antara 24,472\% sampai 39,06 \% sedangkan daerah dengan kerapatan renggang dan tutupan kanopi sedang memiliki nilai kandungan C organik berkisar antara 4,377 \% sampai 10,168 \%.

Tabel 8. Sebaran Jenis Mangrove dan Ekologinya

\begin{tabular}{cccccc}
\hline No & Sedimen & Salinitas (ppm) & Tebal Sedimen C-Organik (\%) & $\begin{array}{c}\text { Jenis } \\
\text { Mangrove }\end{array}$ \\
\hline 1 & Pasir & 47 & $9,5 \mathrm{~m}$ & 35.137 & Ceriops tagal \\
\hline 2 & Pasir & 47 & $9,5 \mathrm{~m}$ & 35.171 & Lumnitzera racemosa \\
\hline 3 & Pasir & 47 & $9,5 \mathrm{~m}$ & 10.168 & Scyphiphora hydrophyllacea \\
\hline 4 & Pasir & 48 & $8,2 \mathrm{~m}$ & 39.060 & $\begin{array}{c}\text {-Ceriops tagal } \\
\text {-Lumnitzera racemosa }\end{array}$ \\
\hline 5 & Pasir & 48 & $8,2 \mathrm{~m}$ & 35.905 & -Avicennia marina \\
-Ceriops tagal
\end{tabular}

\section{KESIMPULAN}

Kesimpulan dari penelitian ini adalah :

1. Fluktuasi perairan laut Pulau Kariumunjawa berkisar antara $47,4-50,8 \mathrm{~cm}$ pada saat pasang, sedangkan saat surut berkisar antara -39,7 sampai $-48 \mathrm{~cm}$, dengan rata-rata elevasi air laut selama musim barat 2019 adalah $-0,054762 \mathrm{~cm}$. Jenis pasang surut di Pulau Karimunjawa adalah campuran condong harian tunggal dengan nilai formzahl 2,39.

2. Pasang surut, distribusi air tanah payau, dan sedimen dasar mempengaruhi pola sebaran mangrove. Daerah yang jauh dari pengaruh pasang surut, namun terletak pada daerah dengan lapisan tanah akuifer yang sumber air nya berasal dari resapan air hujan, dan aliran air dari daerah yang lebih tinggi, ditumbuhi oleh jenis mangrove yang memiliki akar didalam tanah, batang yang tinggi dan diameter yang kecil. Berbeda dengan mangrove yang tumbuh di daerah yang dekat dengan pengaruh pasang surut yang memiliki lapisan tanah akuifer yang airnya bersumber dari air laut, resapan air hujan, dan aliran air dari daratan yang lebih tinggi. Mangrove pada daerah ini memiliki batang yang pendek, diameter yang lebih besar, dan juga akar nafas di tengah batang. Selain itu, mangrove pada daerah ini juga memiliki mekanisme adaptasi terhadap salinitas yang lebih tinggi.

\section{DAFTAR PUSTAKA}

Badan Pusat Statistik Kabupaten Jepara. 2013. Kecamatan Karimun Dalam Angka.

Febriana, R. K. N., Minarto, E., \& Tryono, F. Y. 2017. Identifikasi Sebaran Aliran Air Bawah Tanah (Groundwater) dengan Metode Vertical Electrical Sounding (VES) Konfigurasi Schlumberger di Wilayah Cepu, Blora Jawa Tengah. Jurnal Sains Dan Seni, 6(2), 6-10.

Fitriyah, N. Z. A., Wulandari, S. Y., Widada, S. 2016. Distribusi Kandungan Karbon Organik Total (Kot) dan Bioavailable Phosphate (Bap) dalam Sedimen di Perairan Sluke, Rembang. Jurnal Oseanografi. $5(1): 67-76$. 
Kusnadi, N., \& Fauziah, Y. R. 2010. Strategi Pengembangan Ekowisata Taman Nasional Karimunjawa, Kabupaten Jepara, Propinsi Jawa Tengah. Journal of Chemical Information and Modeling, 53(9), 1689-1699.

Lestaru, A., Saru, A., \& Lanuru, M. 2018. Konsentrasi Bahan Organik dalam Sedimen Dasar Perairan Kaitannya dengan Kerapatan dan Penutupan Jenis Mangrove di Pulau Pannikiang Kecamatan Balusu Kabupaten Barru.Proceeding Simposium Nasional Kelautan dan Perikanan. 25-36.

Mahasani, I. G. A. I., Karang, I. W. G. A., Hendrawan, I. G. 2016. Karbon Organik di Bawah Permukaan Tanah pada Kawasan Rehabilitasi Hutan Mangrove, Taman Hutan Raya Ngurah Rai, Bali. Prosiding Seminar Nasional Kelautan. Universitas Trunojoyo Madura : 33 - 42.

Nursal, Fauziah Y, Ismiati. 2005. Struktur dan Komposisi Vegetasi Mangrove Tanjung Sekodi Kabupaten Bengkalis Riau. J.Biogen.2(1):1-7.

Ongkosongo dan Suyarso. 1989. Pasang Surut. Pusat Penelitian dan Pengembangan Oseanologi (P3O) LIPI, Jakarta.

Perry CT, A Berkeley. 2009. Intertidal substrate modification as a result of mangrove planting: Impacts of introduced mangrove species on sediment microfacies characteristics. J.ecss.81:225237 